\title{
Exploring Thematic Progressions in Two Excerpts From Amma Darko's Faceless
}

\author{
Daniel T. Yokossi \\ Assistant Professor of Applied Linguistics, Faculty of Literature, Arts, and Humanities \\ FLASH-Adjarra, University of Abomey-Calavi, Republic of Benin \\ E-mail: danielshappiness@yahoo.fr
}

Received: October 31, 2021 Accepted: December 11, 2021 Published: December 21, 2021

doi:10.5296/ijl.v13i6.19361

URL: https://doi.org/10.5296/ijl.v13i6.19361

\begin{abstract}
This study explores thematic progressions in two excerpts from Amma Darko's Faceless. The study aims at looking into the different types of thematic progressions used in the selected excerpts to decode there-from the deep meanings linguistically encoded by the author. The study further aims at examining how the different thematic progressions used in the studied texts contribute to their cohesion and contextual coherence. The research appeals to the mixed quantitative and qualitative methodology. Via this method, the number of thematic progression patterns identified has been quantified per excerpt to pave the way to the interpretation of the findings that ensued. The study has arrived at impressive results. Among several others available in the interpretation of the findings subsection, Amma Darko has purposefully not used the Split-Rheme Pattern to avoid a complex writing style that would make her writing not accessible to her readership. The simple linear thematic progression and the overriding theme reiteration patterns extensively used in both texts have allowed the author to emphasize the key thematic points of the studied texts. Moreover, the theme reiteration development strategy used in both texts has provided them with clear focuses. Some of these include skin bleaching, tradition and marriage in Africa, street children, women's life conditions in Ghana to name but a few. For deeper meanings decoding in the studied excerpts, further studies on discourse-semantics, contextual coherence, conjunctive and lexical relations, as well as experiential and interpersonal meanings could pick up from this article findings.
\end{abstract}

Keywords: Theme, Thematic progression, Reiteration, Cohesion, Coherence

\section{Introduction}

There are several ways of developing a text cohesively and coherently. As a matter of fact, Halliday (1985:302-9) acknowledges three main types of text development namely 
elaboration, extension and enhancement. Eggins (2004:324) admits other methods of text development called thematic progressions. This study is focused on these ones. In fact, thematic progressions are concerned with how thematic elements follow each other. Though other scholars (Belmonte \& McCabe-Hidalgo, 1998; Wang, 2007; Li \& Fan, 2008; Tan \& Sun, 2010; Zhang \& Li, 2009)) recognize other types of thematic progressions, this study focuses on only three types: theme reiteration, zig-zag and multiple-rheme thematic developments.

Any reader of Amma Darko's Faceless acknowledges that she has strategically and thematically encoded deep meanings in her novel. As a consequence, this study explores the above mentioned types of thematic progressions in two excerpts purposefully culled from her pinpointed novel to examine how these ones have allowed her to create clear cut focuses around which her important messages have been encoded. The study further assesses the extent to which the thematic progressions looked into have contributed to the scrutinized texts cohesion and contextual coherence.

The textual meaning division of the Systemic Functional Linguistics (henceforth SFL) has so far been of great interest to researchers from various horizons. Likewise, thematic progression theories, sub-components of the textual meaning, have also captured a lot of researchers' attention for texts analyses from different perspectives. In this vein, many studies have shown that patterns of thematic progression depend on texts contents. Indeed, a text with the same genre has similar thematic progression patterns (Zang \& Wang, 2001). Besides, Wang (2008) carried out a comparative study in China involving abstracts of both Chinese and English science technology papers. He reached the conclusion that TP models of SFL are key components and significant devices for textual analysis.

Lock (1996) and Eggins (2004) contend that determining the ways thematic elements succeed each other largely contribute to a text cohesion and coherence. In that regard, Danes (1974) argued that the progression in the ordering of utterance themes and their rhemes determines the organization of information in texts.

Nwogu (1990) in his analysis of specialized medical texts noticed that linear progressions were preponderant in the Methods and Results sections of the medical research article. Nevertheless, he noted a preference for the constant progression in the research article. Conversely, Nwogu (1990) noted a marked preference for linear progressions in popularized accounts of medical texts on very similar subjects. Thomas, (1999) analysis of texts carried out in the field of telecommunications would seem to echo these results by Nwogu (1990)

Dubois (1987), Nwogu and Bloor (1991) have investigated thematic progression types in medical and biomedical research texts. They based their studies on naturally occurring data. Both scholars found that the zig-zag thematic progression pattern and the theme reiteration or constant theme pattern are the most frequently occurring in their studied texts. However, whereas Nwogu and Bloor (ibid) recorded multiple-theme patterns in their research article data but not in their more popular medical texts, Dubois (ibid), working with biomedical research texts, recorded one single example of this type. As a result, she reduces Danes' (1074) three types to two, one themic and the other rhemic, each of which may be simple or multiple, 
contiguous or gapped. As such, the third thematic progression pattern is subsumed under the themic type.

Dawning (2001) carried out a research work on thematic progression in extracts from more popular text types, all encountered within the 'leisure' sections of newspapers and magazines: first, a feature article by a wildlife expert, and second, extracts from the 'travel' sections. She found out that the multiple-theme pattern is the overriding one in the studied texts. Then, she concludes that the studied excerpts are instances of professional writing whose rhetorical purpose ranges from entertainment to persuasion. She believes that Danes' (1974) model allows revealing the internal organization of texts.

Shieh and Lin (n.d.) conducted a research work on Thematic Progression Patterns and the Texts of the Department Required English Test. In their study, they Analyzed extracts taken from the DSTs (individual test component called the Discourse Structure Test) of DRET (the Department Required English Test). They aimed at exploring theme-rheme relationship and thematic progression in their selected texts to diagnose students' reading difficulties and make suggestions towards solving them. The results of their study show that unmarked theme, constant and linear Thematic Progressions (TP) prevail over the other TP types in the analysis. They concluded that teachers can use theme and rheme construct as a valuable instrument especially as it allows them to explain to students where they are losing effectiveness while reading due to problems with either TP or thematic selection, or both.

Kuswoyo and Susardi (2017) carried out a research work on problems on SFG thematic progression in ESL academic writing. The paper examines the problems caused by the misuse of theme and rheme in the thematic progression of fifth semester students' writing. The findings of the research reveal that there are six problems in the thematic progression of the examined students' writing. These include the problem of brand new theme, the problem of double rheme, the problem of empty rheme, the problem of empty theme, the problem of overuse of constant theme pattern and the problem of confusing selection of textual theme. The researchers also identified four other new problems. Such problems include the problem of incomplete clause, the problem of error in choosing topical theme, the problem of unneeded textual theme, and the problem of double textual theme. To round off, the researchers recommend that students be aware of the flow of theme and rheme of thematic progression in their writing.

Al-Bazzaz and Al-Shajlawi (2018) investigated the use of thematic progression in scientific articles written by Iraqi EFL learners of English language, in the hope that it would be helpful for teachers of writing to non-native students. To arrive at this, the researchers dealt with the analysis of professional scientific essays written by Iraqi EFL learners in two different disciplines (Medicine and Engineering). They used Daneš's (1974) thematic progression patterns as a model of analysis in their study. The findings of the study shows that simple linear thematic progression is the most used one while derived and split thematic progression patterns are less used. The study concludes that Iraqi EFL Learners faced a difficulty in presenting a well organized text. 
Drid (2019) also carried out a research work on thematic progression in online Algerian newspaper articles: insights to producing coherent texts. The paper presents an analysis of the preferred thematic progression patterns used in a sample of online English versions of Algerian news articles written by Algerian journalists and appearing originally in Arabic. The study aims at detecting the recurrent patterns in this media genre. The results of the research point toward a more frequent use of simple linear progression and constant theme progression. Derived theme and split theme patterns are rarely used, while split rheme progression does not feature in the data. Significant rates of ruptured themes are also recorded. The paper concludes by deriving useful insights as to finding ways of upgrading the writing of more coherent newspaper articles based on careful consideration of thematic progression.

In other respects, Kizil and Kushch (2019) conducted an investigation entitled thematic progression and its types in English literary and legislative texts. The researchers argue that texts of different genres and the same language exhibit different patterns of Thematic Progression. According to them, this indicates that thematic progression, its patterns and their varieties are genre specific. To prove this, their article dwells on the theme progression patterns and peculiar features of their Theme-Rheme organization in texts of literary and legislative genres. The researchers disclosed that while linear-constant thematic progression patterning is typical of a literary text, a legislative text is mainly based on the constant-linear thematic progression pattern. They further added that constant linear thematic progression patterning in the legislative text contributes to its informativeness, argumentativeness, unambiguity, and detailed specification of the given information. In comparison with the legislative text, the literary text has a variety of thematic progression patterns made of linear thematic progression, derived thematic progression and elliptical progression types. Regular linear-constant thematic progression patterning employed in the literary text helps to unfold textual information successively that contributes to its coherence and more effective perception.

To my best knowledge, and as it can be noticed from the literature reviewed so far, no research work has been carried out on thematic progression in Amma Darko's Faceless and even less in the selected excerpts under consideration in this article. Hence it is needful to carry out this research work to extend, via its findings, the limits of the existing scientific knowledge within the field of thematic progressions.

\section{Methodology}

This study appeals to the method of discourse analysis. As a matter of fact, Goldman and Wiley (n.d.) contend that written text discourse analysis is a method for describing the ideas and the relations among the ideas that are present in a text. Via this method, the study describes and analyses how both the structure and contents of the selected excerpts encode ideas and what the relations among them are. The selection of the texts is based on the criterion that they yield to the study of thematic progression in hand. To allow the easy identification of the thematic progression patterns embedded in the selected texts, the latter ones have been first broken down into their clause constituents then analyzed using the textual meaning analysis keys presented at the beginning of the appendices. The study also 
calls for the mixed quantitative and qualitative methodology. Using the quantitative method, the number of the different types of thematic progressions identified in the selected excerpts have been counted and tabulated statistically. The qualitative method that ensued has allowed to infer, via interpretation, the meanings encoded through the various types of thematic development embedded in the studied texts.

\section{Theoretical Orientation of the Study}

Thematic progression has to do with theme contribution to text cohesion and coherence. More specifically it is concerned with how thematic elements succeed each other (Eggins, 2004:323). The Czech linguist Danes (1974) considers thematic progression as "the skeleton of the plot" (p. 114). Thematic element succession may be carried out accidentally in which case the new theme comes from outside the text. It can also be achieved cohesively and is therefore described as thematic progression. As a matter of fact, thematic progression patterns are essentially of three categories: the zig-zag pattern, theme reiteration pattern and the multiple themes Pattern (Eggins, 2004).

In the zig-zag thematic progression pattern (Eggins, 2004: 324) categorized by Bloor, T. \& Bloor, M. (1995) and Danes (1974) as Simple linear progressions, an element of the Rheme of a clause becomes the Theme of a subsequent clause. Here is an illustration:

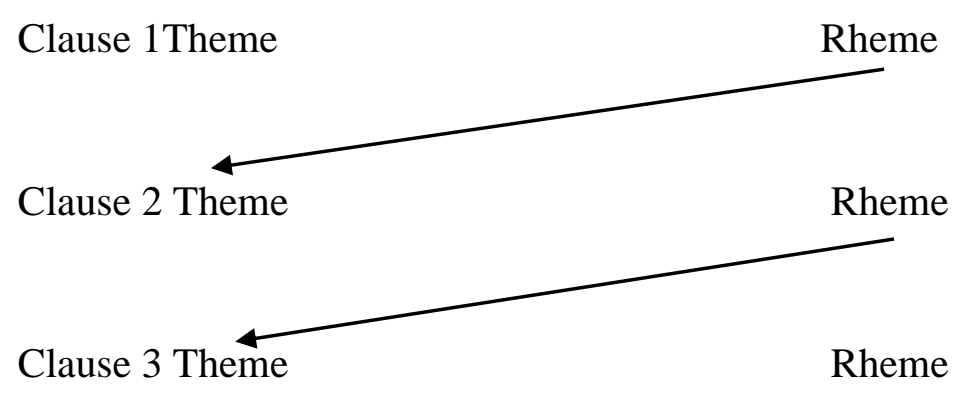

Figure 1. The zig-zag pattern of thematic development (adapted from Eggins, 2004, p. 324)

A further typical illustration of the zig-zag thematic progression is the one in the following example, where the noun phrase police officer introduced in the Rheme of the first hypotactic clause gets picked up in the subsequent clause as theme:

Eg. They were on the way to their office when they ran into a police officer. The police officer stopped them and asked them for their credentials unexpectedly.

Eggins, (2004) calls the second thematic progression theme reiteration. This thematic development pattern is also referred to as "Continuous or Constant Theme" (Bloor \& Bloor, 1995; Chao, K. H., 2002; Danes, 1974). In fact, in this type of thematic progression, themes got derived from a hyper theme. Such a thematic pattern is often found in short biographical passages, textbooks, descriptions of factual information and in narratives. A proper example of theme reiteration is the one provided in the following text where the theme in every single clause refers either to the noun phrase jacket or to the pronoun it as the main topic of the text:

Jacket is the name given to a piece of clothing worn on the top half of the body over a shirt. It has sleeves and fastens down the front. Jacket is also used to refer to a loose paper cover 


\section{I Macrothink}

International Journal of Linguistics

ISSN 1948-5425

2021, Vol. 13, No. 6

for a book usually with a design or picture. It is sometimes defined as an outer cover around a hot water pipe. Jacket in another context is the skin of a baked potato.

The multiple-theme pattern also known as the multiple-rheme pattern is the third common type of thematic progression. It is also referred to as a split-rheme pattern (Bloor, T. \& Bloor, M., 1995). In this type, the rheme of a clause has two or three components, each of which is picked up and made theme in subsequent clauses as illustrated bellow:

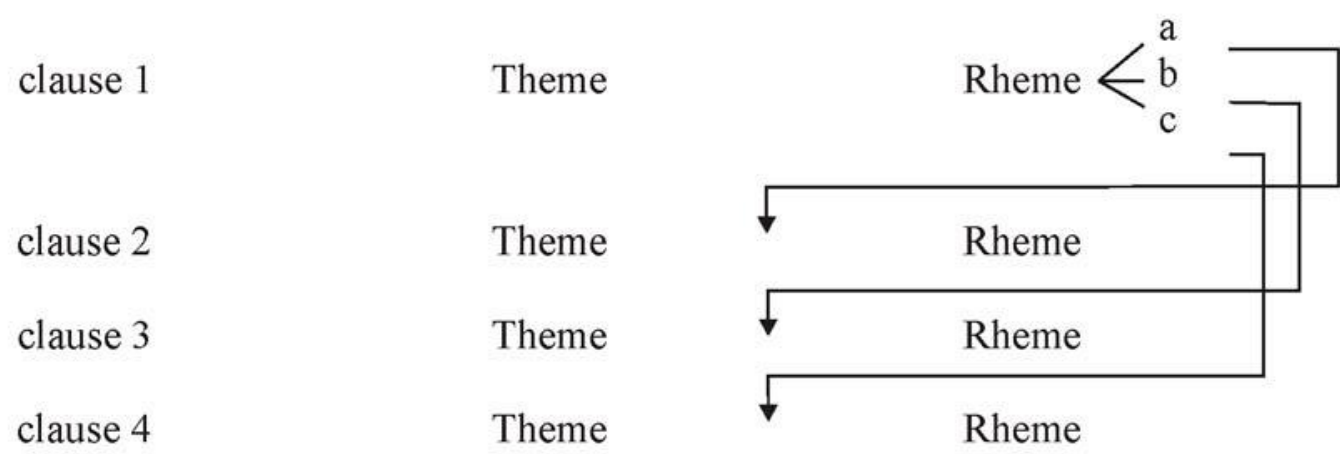

Figure 2. The multiple-rheme pattern of thematic progression (adapted from Eggins, 2004, p.325)

The multiple-theme is common in expository texts. The following is a further illustrative example of multiple-theme pattern of thematic development: A bicycle has three main parts: the handlebars, the frame and the wheels. The handlebars are used for steering the bicycle. The frame is the supporting structure of the bike that gives it its shape. As for the wheels, they serve to move the bicycle.

The above presented three types of thematic progression are going to be explored or examined in the selected texts using textual meaning analysis keys within the systemic functional approach framework.

\section{Thematic Progressions Examination in the Selected Excerpts}

The different thematic progression patterns introduced in the theoretical framework have been examined in the selected excerpts and the results are statistically tabulated as follows:

Table 1. Recap statistical table of the recorded types of thematic progressions in both excerpts

\section{Types of Thematic Progressions}

Simple linear thematic progression
Excerpt N01

$38(17.43 \%)$
Excerpt N02

$24(08.33 \%)$

Constant theme

$180(82.56 \%)$

$264(91.66 \%)$

Multiple theme

$00(00 \%)$

$00(00 \%)$ 
As it can be noticed from the above statistical table, the multiple-theme or multiple-Rheme thematic progression pattern has not been recorded in either of the analyzed excerpts. Conversely, thirty-eight (38) simple linear thematic progressions have been recorded in the first excerpt. Indeed, they represent $17.43 \%$ of the total number of thematic progressions embedded in the excerpt. The same thematic progression type has been recorded in the second excerpt in lower proportion. Here twenty-four (24) simple linear thematic progressions have been identified representing $08.33 \%$ of the overall thematic progressions recorded in the excerpt. The overriding thematic progression in the studied excerpts is the continuous/constant theme or theme reiteration. In the first excerpt, one hundred and eighty (180) constant themes have been recorded. Indeed, they represent $82.56 \%$ of the thematic progressions identified in the excerpt. The second excerpt count largely more theme reiteration patterns than the first one. Two hundred and sixty four (264) theme reiterations have been recorded in it. In terms of percentage, they equal to $91.66 \%$ of the recorded thematic progressions in the excerpt. While the first excerpt count a total number of two hundred and eighteen (218) thematic progressions, the second excerpt count two hundred and eighty-eight (288) thematic progressions. All in all five hundred and six (506) different thematic progressions have been recorded in both studied excerpts. These statistical collected data encode deep meanings that are going to be decoded in the subsection entitled findings and interpretation hereafter.

\section{Findings and Interpretation}

The collected data clearly show that the author Amma Darko has adopted the simple linear thematic progression and the constant theme progression patterns to weave the cohesive and coherent ties in her selected texts. The absence of the third type of thematic progression viz. the multiple-theme pattern in both selected excerpts is neither meaningless nor surprising at all. As a matter of fact, though the multiple-theme pattern often provides the underlying organizing principle for a text, both the theme reiteration pattern used in so large proportion in both texts added to the zig-zag strategies, validly replaced it to operate the same result. More to the point, the absence of this type of thematic progression in the scrutinized texts, is symptomatic of the fact that Amma Darko has adopted a simple writing style to make her writing accessible to her readership. Indeed, a careful examination of the studied excerpts shows that the author has preferred using the constant theme and zig-zig patterns to elaborate on every single one of the key thematic points of the excerpts.

To descend to particulars, the theme reiteration development strategy used in both texts has provided them with clear focuses. It is good to look into the elements that are constantly reiterated around which the focuses in each text are set. Looking into these elements in the first excerpt, one discovers that they include the rasta hairdressing woman, the Almighty God, Kabria, the dead body of a street girl, the senior and junior apprentices of the rasta hairdresser. 
Indeed, serious cohesive and coherent ties have been built around these personae in the first excerpt to convey serious messages about the evils that undermine Ghanaian women's and children's life conditions. To start with, using the constant theme pattern, Amma Darko in the first excerpt has subtly raised the problem of skin bleaching by African women. In the first paragraph of the first excerpt the problem has been thematically reiterated thirteen times via both simple linear and continuous theme progression patterns. This can be witnessed in clauses ranging from five (5) to seventeen (17). Reiterating the issue this number of times, in just one single paragraph in such a continuous way, accounts for its importance and seriousness. Actually, the author has vehemently denounced the practice. The following quotations from the first excerpt are very good instances of her strong disapprobation of that demeanor that I typify here as self denial: "The woman had bleached her skin from head to toe, which apparently caused our uncanny creator to unleash his fury in grand style upon her." Through this quotation, one understands the author's clear-cut stand about the matter. In fact, for the author, the practice is one that is not only disgusting but also one which deserves God's severe punishment to discourage those practicing it. In the twelfth clause one can read: "Her punished body found solace in a cute but pathetically mismatched sleeveless dress." These two quotations have deep meanings implications. Careful reading of both above provided quotations let one understand that bleaching one's skin has both corporal and spiritual negative consequences. One of the negative spiritual consequences is that such practice arouses God's anger against those involved in it. As for the corporal negative consequences they are too many. Some of them have been mentioned by the author in the first paragraph of the first excerpt as follows: "She was a multi-colored parody of nature's original handiwork." Additionally, "Her perfume clashed with the odour of skin whose entire outer protective layers had been gradually and persistently peeled away."Truly, Amma Darko views the practice as an insult to God who has purposefully created and endowed Africans with ample melanin to withstand the harsh rays of the sun. Moreover, God knows why he has created the African black and he is certainly proud of the African skin color. So why try to change such a wonderful skin color? Doing so is trying to interfere with God as the author herself said it in the following (the eighth and ninth clauses of the first excerpt): "the Creator least expected this woman, who had dared to interfere with His plans, to have bleached herself." African women in particular should be proud of their skin color and solemnly preserve it for their health, beauty, and honor.

The other focus of information underscored by the simple linear and theme reiteration progression patterns as used by the author in the first and second excerpts is that related to the corpse of a street girl found behind a blue rasta hairdressing Kiosk salon at Agbogbloshie market place. Indeed, street children and their precarious life conditions have been the key concern thematically reiterated all through both excerpts. In both excerpts, great attention has been paid to the case of Baby $\mathrm{T}$, a street child dead of what no one knows miserably and disgracefully in the open market place. Kabria investigated about the case but couldn't find any good information about it. Even the hairdresser behind whose kiosk the girl's dead body is found could not give the least information. This poses serious problems that the author is trying to call attention to via her studied texts. It is all about a girl, therefore a future woman divinely destined to educate generations in the future. It was reported to Kabria that the FM 
station journalists went to witness the corpse but could not break news about it. The police likewise including the people who gathered around the corpse know nothing about what or who really killed the girl, where and who the parents of the late girl could be. The case portrayed this way is evocative of parents' abdication. It is further illustrative of the political leaders' carelessness and happy-go-lucky attitude towards street children in Ghana. Knowing that journalists' basic job is to break news, one is surprised that they are now afraid to say a single word on the case, and just have to remain silent on the situation. This is indicative that the freedom of information and expression was confiscated in Ghana during the period Faceless got published. Alternatively put journalists had certainly lost their freedom of information and expression for some political reasons by the time the novel was published. Street children problem in Ghana seems of no concern to parents, families, the state, educational and political bodies. A close look into the people giving information about the dead girl viz. a hairdresser and her apprentices is illustrative of the assertion. One would expect important personalities, orphanage representatives raising money here and there to take care of abandoned children living in streets as well as political leaders to get involved in the matter and try to understand its pros and cons especially as it is an insecurity case. Alas and alack! Neglecting children's problems to that point in an African country as depicted in the studied texts here is symptomatic that African societies are really falling apart.

In other respects, the character of Kabria, representative of the organization called MUTE is revelatory of the author's dream for street children. Through the diligence of that character getting to the place where a girl's dead body is found immediately as she heard about it is expressive of Amma Darko's call to competent social and political authorities' diligence to care for street children problems. She is also certainly suggestively recommending that non-political institutions and organizations be set up to manage street children problems and help find sustainable solutions to that social rampant plague in almost all African countries and in Ghana in particular.

A number of topical, textual and interpersonal themes have been largely reiterated in the studied excerpts to raise another focus of concern. Reading between lines throughout the constant themes ranging from clause 151 to 159 of the first excerpt, one decodes that Amma Darko is worried about African women's life conditions jeopardized by some African traditions that keep hold of women into deadly marriage bondages. To show to what extent the problem she is pointing to is crucial, she has purposefully used the continuous theme progression pattern to call attention to the importance of the social problem she is pointing at. Many African women are married to the types of men Amma Darko describes in the one hundred and thirty-fifth clause of the first excerpt as foolish and irresponsible. In the fifty-second clause of the second excerpt she calls those kinds of people "smallish men". Moreover, in the eighty-seventh clause of the same excerpt, she says through the character of MaaTsuru that "men are animals" and added in the eighty-eighth clause that "they have no mercy". Even the name of the man MaaTsuru is married with: POISON, who has left her without notice for what reasons she can't tell, is evocative of the danger some men represent to women. Such men just content themselves with impregnating women but are not ready to take care of the pregnancies and children resulting from them. They are not ready to bear any 
pregnancy responsibilities either. They are just proud of giving their last name to their children at women's expense. For example, the hairdresser complaining about such men in the first excerpt said: “...I also need to save something to cater for my daughter. Her upkeep and education is all upon my head." This, indeed, accounts for men's total irresponsibility. To get her message across, she has used theme reiteration and the simple linear theme progression patterns from the sixty-ninth clause to the eighty-fifth one. Using these patterns persistently as she does is evocative of the fact that what she is writing about is serious and real. However, these ways of portraying men with exaggeration evokes Amma Darko's feminism in her literary prose fiction.

In excerpt one Amma Darko, through the character of the hairdresser used both the zig-zag theme progression and theme reiteration patterns to show how such attitudes of some men cause women to suffer. In fact the author considers such men's behaviors as ones breaking and collapsing African families' ties. MaaTsuru's family is a good instance. Unfortunately the scourge is backed up by some strong traditional foundations as it can be witnessed in the long quotation below by Kabria from the first excerpt:

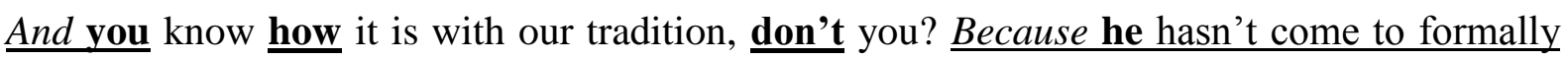
divorce me, $\underline{I}$ am forced to continue to wear his ring and stay married to him. $\underline{\text { Yet he }}$ is gone.

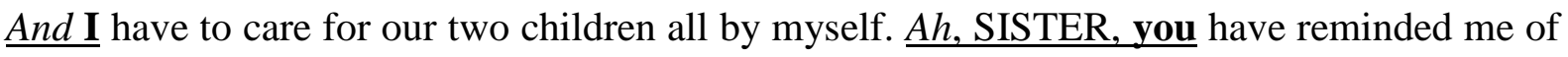
my pain. Ah!"

The above quotation implies that many African women remain in marriage bondage whatever their sufferings are, against their own will, just because their traditions have prescribed it so. A whole lot of them would have made amends for their broken marital life in the absence of such conservative traditions. By depicting the case this way the author is certainly inviting Africans to reconsider some aspects of their traditions that impede self blossoming and as an indirect result families' blooming and nations' sustainable development.

Amma Darko has not just contented herself with criticizing men's wickedness only. She also finds fault with women themselves. Examining some of her characters' statements, one understands that a large number of women nowadays are enduring ill-treatments and suffering tortures from their husbands because of themselves. As an example, Fofo's contention when addressing MaaTsuru her mother in the following continuous themes illustrates this: "...You knew What you were doing When you chose him over..." From this quotation it can be implicitly understood that some women have paved ways for the disgraceful and deadly marital life conditions they are victims of today via their irresponsible attitudes. This depiction of the causes of women's life conditions by Amma Darko is certainly aimed at letting women know that if they really want to see improvement in their shameful, dishonorable poor marital living conditions, they need to change their reckless ways as well.

One of the causes of street life as raised by Amma Darko in the studied excerpts is the one evoked in Fofo's statement in the following quotation: "And HAD I not got the good sense to leave home, he probably would have made you send me away too to work for some women to make money for you four to leave on. No?." using the reiteration theme pattern to 
introduce the matter as done here by the author reveals that the matter being written about is important and recurrent in some African countries especially in Ghana. As a matter of fact, it can be drawn from the above quotation that many children today are in the streets because of their parents' irresponsibility. As it can also be decoded, the social role incumbent upon parents is inverted to fall to children. What a pity! How can children be compelled to do whatever work to feed their parents? Amma Darko is calling attention to the extent to which social values have fallen apart in Africa and in Ghana in particular. At the same time, the author is denouncing the practice as she sees that it is a good thing for a child to leave home under such circumstance to escape hard labor. The author is also hereby conveying the message that a solution needs to be found to the problem. Among several others, parents should manage to give birth to the exact number of children they are sure to be able to take care of. They should stop exploiting their children and rather work hard to cater for their basic needs at least. Laws against exposing children to hard labor have to be enforced in Ghana in particular and in all the African countries where they are so far not applied.

To round off, the simple linear theme progressions and particularly the theme reiteration patterns as used in the studied texts have largely contributed to their cohesion and contextual coherence. Actually the way the author has used the simple linear thematic progression and the theme reiteration has created excellent cohesive ties within the studied texts. This allows readers to know where each of the issues written about by the author depart from and how they unfold. Both selected excerpts also have both situational and generic coherence. They have situational coherence as one can think of one field to which all the clauses or sentences of each excerpt relate. The clauses of the first excerpt relate to an inquest on the death of Baby $\mathrm{T}$ while all the sentences of the second excerpt relate to information about Baby T's death. Likewise both excerpts are generically coherent as they pertain to a common narrative genre.

\section{Conclusion}

This study has explored thematic progressions in two excerpts from Amma Darko's Faceless from a systemic functional approach. Indeed, the research aims at examining the different types of thematic progressions embedded in the selected excerpts and how they have been technically used by the author not only to encode deep meanings but also to contribute to the studied texts cohesion and coherence. To reach such objectives, the study has appealed to the mixed quantitative and qualitative research method. Via this methodology, the collected data have been statistically quantified, organized, described, and related percentages calculated to pave the way to the interpretation of the findings that follows. The research has interestingly made important findings as it can be witnessed in the foregoing subsection of the article. Among several others, the female writer has adopted the simple linear thematic progression and the constant theme progression patterns to weave the cohesive and coherent ties in her selected texts. Moreover, the absence of the third type of thematic progression viz. the multiple-theme pattern in both selected excerpts is symptomatic of the fact that Amma Darko has adopted a simple writing style to make her writing accessible to her readership. A careful examination of the studied excerpts shows that the author has preferred using the constant theme and zig-zig patterns to elaborate on such key thematic points of the excerpts as skin 


\section{Macrothink}

International Journal of Linguistics

ISSN $1948-5425$

2021, Vol. 13, No. 6

bleaching, tradition and marriage in Africa, street children, women's life conditions in Ghana to name but a few.

The present research work has explored only three types of thematic progressions in the selected excerpts following Eggins's (2004) perspectives on the theory of thematic progressions. Such state of affairs opens up avenues for further investigations of such other thematic progression types elaborated on by scholars like Danes (1974), Wang (2007) as derived hyper thematic progression, concentrative progression and crossing pattern for deeper meanings grasping in the studied texts. The study has also paved the way to such further areas of scientific researches to investigate in the studied texts for further meanings decoding as discourse-semantics, contextual coherence, conjunctive and lexical relations, as well as experiential and interpersonal meanings.

\section{References}

Al-Bazzaz, M. A., \& Al-Shajlawi, A. N. (2018).Thematic Progression in Iraqi Scientific Articles. International Journal of Language and Linguistics, 5(2), 126-131. https://doi.org/10.30845/ij1l.v5n2p15

Belmonte, A., I., \& McCabe-Hidalgo, A. (1998). Theme-Rheme Patterns in L2 Writing. Didáctica (Lengua y Literatura), 10, 13-31.

Bloor, T., \& Bloor, M. (1995). The Functional Analysis of English: A Hallidayan Approach. London: Arnold.

Chao, K. H. (2002). Thematic Progression in the Argumentative Essays of EFL Senior High School Students. Unpublished master's thesis, National Chengchi Univerisity, Taipei city, Taiwan.

Danes, F. (1974). Functional sentence perspective and the organization of the text. In F. Daneš (Ed.), Papers on Functional Sentence Perspective (pp. 106-128). Prague: Publishing House of the Czechoslovak Academy of Sciences.

Darko, A. (2013). Faceless. Ghana: Subsaharan Publishers.

Drid, T. (2019). Thematic Progression in Online Algerian Newspaper Articles: Insights to Producing Coherent Texts. Khazar Journal of Humanities and Social Sciences, 22(4), 68-94. https://doi.org/10.5782/2223-2621.2019.22.4.68

Dubois, B. L. (1987). A reformulation of thematic progression typology. Text 7(2), 89-116. https://doi.org/10.1515/text.1.1987.7.2.89

Eggins, S. (1994). An Introduction to Systemic Functional Linguistics (1st ed.). London: Publishers.

Eggins, S. (2004). An Introduction to Systemic Functional Linguistics (2nd ed.). New York \& London: Continuum.

Halliday, M. A. K. (1995). An introduction to functional grammar. London: Edward Arnold. 


\section{Macrothink}

International Journal of Linguistics

ISSN 1948-5425

2021, Vol. 13, No. 6

Halliday, M. A. K., \&Hasan, R. (1976).Cohesion in English. London \& New York.

Kizil, M., \& Kushch, E. (2019).Thematic Progression and its Types in English Literary and Legislative texts. Advanced Education, 12, 181-187.

Kuswoyo, H., \& Susardi. (2017). Problems on SFG thematic progression in ESL academic writing. Leksema, 2(1), 1-13.

Lock, G. (1996). Functional English Grammar: An introduction for second language teachers. Cambridge, New York: Cambridge University Press.

Longman Li, J., \& Fan, X. T. (2008). Application of Patterns of Thematic Progression to Literary Text Analysis. Journal of Dalian University, 29(4), 59-62.

Nwogu, K. N. (1990). Discourse variation in medical texts: schema, theme and cohesion in professional and journalistic accounts. Monographs in Systemic Linguistics (vol. 2), University of Nottingham.

Nwogu, K., \& Bloor, T. (1991). Thematic progression in professional and popular medical texts. In E. Ventola (Ed.), Functional and Systemic Linguistics: Approaches and Uses (pp. 369-384). Berlin: Mouton de Gruyter.

Tan, J. H., \& Sun, W. G. (2010). Enlightenment of Progression Patterns of Theme and Rheme in English Teaching. Journal of Xuzhou Normal University (Philosophy and Social Sciences Edition), 36(1), 140-143.

Thomas, S. (1999). Organisation thématique et qualité textuelle: une analyse des difficultés rencontrées par des élèves-ingénieurs francophones lorsqu'ils rédigent en anglais. Thèse dedoctorat Université Paris V.

Wang, J. L. (2007). Patterns of Thematic Progression and Discourse Production. Journal of HuBei TV University, 27(7), 126-128.

Wang, L. J. (2008). Comparative study on Thematic Progression Patterns in Abstracts of English and Chinese sci-tech Papers. Journal of Huang gang Normal University, 28(6), 49-51.

Zhang, H., \& Li, X. (2009). Contrast Studies on Thematic Progression in English Newspaper and Broadcasting News Texts. Journal of Xin Jiang Education Institute, 25(3), 117-120.

Zhang, W. P., \& Wang, Z. L. (2001). Patterns of Thematic Progression and Genre. Journal of Zhuzhou Teachers College, 6(6), 68-71. 


\section{Macrothink}

International Journal of Linguistics

ISSN 1948-5425

2021, Vol. 13, No. 6

\section{Appendices}

The identification of the thematic progression patterns embedded in the selected excerpts is done using the SFL theme analysis keys as presented below.

Key:

Theme is underlined

Textual theme: in italics

Interpersonal theme: in CAPITALS

Topical theme: in bold

Dependent clause as theme: whole clause in bold

\section{Excerpt N01}

1. She recognized the salon owner from her huge portrait in one corner. 2. She was both a puzzle and a challenge to the wisdom of Mother Nature, 3.who, when unduly interfered with, 4. left in her trail dire consequences. 5. The woman had bleached her skin from head to toe, 6 . which apparently caused our uncanny creator to unleash his fury in grand style upon her. 7. Having endowed the African with ample melanin to withstand 'until calleth' the harsh rays of the African sun, 8. the Creator least expected this woman, 9. who had dared to interfere with His plans, to have bleached herself, 10. So she ended up fair from face to ankle, dark at the feet, which refused to succumb to the dictates of her bleaching soaps and creams, purplish around her eyes and cheeks and underarms. 11. She was a multi-colored parody of nature's original handiwork. 12. Her punished body found solace in a cute but pathetically mismatched sleeveless dress, 13. While her stubborn feet triumphed in a pair of fine white slippers 14 Her perfume clashed with the odour of skin 15 . whose entire outer protective layers had been gradually and persistently peeled away, 16. While at her service to obey and carry out her orders, were eight young apprentices.

17. "SORRY!" 18. she asked, 19. when at last she noticed Kabria, 20. "you should have come earlier.21. We are fully booked up for the day. 22. CAN you come back tomorrow?"

23. In reply, Kabria greeted loudly, "Good Morning”. 24. She gave Kabria a sharp look.

25. "I am not here to plait my hair, madam." 26. Kabria rattled on giving her no time to recover enough to throw her out. 27. "I am from an organization called MUTE," 28. and stretched out her job ID card.

29. The woman got confused. 30. "So?" she said tersely, ignoring the card.

31. Kabria put it back in her bag. 32. "PLEASE!" she beseeched, 33. "I am here about the body 34 . that was found behind your salon last week." 
35. The woman became alarmed. 36. Kabria didn't risk a pause. 37. 'I am here to find out 38. whatever I can for a report39. I am working on. 40. PLEASE, CAN you tell me something? 41. Anything you saw 42. or heard 43. or know?"

44. The woman grew more bewildered.

45. "SISTER, she shrieked at Kabria, 46. "HAVE I done something to you? 47. DO you know me from somewhere? 48. HAVE I, maybe, snatched your husband from you?"

49. "PLEASE NO."

50. "Then why should you come51. and spoil my day for me this way? 52. DO you live here in Accra? 53. Or MAYBE you are lucky. 54. You have somebody abroad remitting you regularly, 55. So you chop dollars, eh?"

56. "NO."

57. "YES. 58. You chop dollars. 59. I can see it. 60. That is why 61. you don't have problems of your own. 62. Look," she said 63. and gave Kabria no opportunity to interrupt again, 64. "just in case you haven't noticed, 65. I am here to work66. and make my chop money for the day. 67. See all the apprentices too? 68. They are all expecting something from me by the close of the day, 69. on top of which I also need to save something to cater for my daughter. 70. Her upkeep and education is all upon my head. 71. So if you think you can just......."

72."MADAM!"

73. "Let me finish! 74. You think 75. I am here to add police work to my hairdressing job? 76. MY DAUGHTER...oh! God! Raising her eyes onto the heavens, 77. she said 78. "I thank you 79. That she is my only child. 80. Thank you!" leveling her eyes again with Kabria's, 81 . she continued, 82. "she is wholly and exclusively my responsibility. 83. And you know 84 . What that means in these times, 85. don't you? 86. So don't come 87. And trouble me this Tuesday morning. 88. Don't come 89. And make somebody's palaver my palaver by force. 90. Not one cidi do I get from the man 91. who fathered my little girl. 92. The only thing that man ever gave her93. was his last name.94. It cost him not a pesewa. 95. Yet he made sure 96. That somehow, I paid for it. 97. He came 98. and quaffed six bottles of beer at my expense. 99.Six! Bought solely from my sweat and toil. 100. After which he did the disappearing act from our lives, 101. NEVER to return again. 102. So PLEASE, don't come 103. And add to my woes. 104. If a street girl's body was found behind my salon, 105. $\underline{\text { So }}$ what? 106.As for me, what should I do? 107. DO I look to you like the one 108. who killed her?"

109. Kabria smiled. 110. She knew on impulse 111 how she was going to get through to the woman.

112. "You know something?" 113. she began impassively, 114. "I am also stuck in a similar soup."

115. The woman frowned. 116."What similar soup?" 
117. "SISTER," Kabria began, calmly 118. As the lie she was about to tell at the expense of Adade, 119. "DO you think 120.it was for nothing 121. That our elders coined the saying 122. That until you hear the plight of another, 123. you think 124. yours is the worst in the world? 125. Why should I be standing here 126.making such a fool of myself 127. and asking questions 128. the police should be asking, 129. But for the same situation I am in as you. 130. You were thanking God for your only one child? 131. SISTER, I have two to deal with. 132. Two! Who both depend wholly on me. Two!

133. The sense of solidarity Kabria was hoping for 134. kindled like a candle flame in the woman. 135. "You too were cursed with a foolish and irresponsible man? 136. She spat.

137. Kabria's heart churned for Alade. 138. The poor man was definitely other things. 139. But foolish and irresponsible! 140. NO! 141. That he definitely wasn't. 142. Yet, aluta, as they say, must continua.

143. "MY SISTER, see my finger?" 144. Kabria continued, stretching out her left hand. 145. "He married me, 146. oh, then after our first child, disappeared, 147. came back four years later, 148. begged for my forgiveness,149.got me pregnant again 150. and disappeared once more. 151. And you know 152. how it is with our tradition, 153. don't you? 154. Because he hasn't come to formally divorce me, 155. I am forced to continue to wear his ring 156. and stay married to him. 157. Yet he is gone. 158. And I have to care for our two children all by myself. 159. Ah, SISTER, you have reminded me of my pain. Ah!"

160. By now, the woman was wholly awash with guilt

161. "Oh SISTER, I am sorry!" 162. she beseeched Kabria. 163. "ME aaah, I don't know 164.why I keep bringing up the foolish man. 165. It's just that the six bottles 166. he came to quaff at my expense...ah! 167. What's the use? 168. Forget it! 169. PLEASE have a seat. 170. SORRY I kept you standing. 171. Sit down."

172. Kabria took the seat, feeling like both Judas Iscariot and Archimedes rolled in one.

173. The woman did not let her pose her question again. 174. She launched into her response.

175. "To tell you the truth, my sister, 176. what at all am I even supposed to know?" 177. and shrugged.

178. Kabria broke into a cold sweat. 179. WAS that all that the woman was going to tell her 180. After she had so cold-bloodedly massacred Adade's reputation? 181. All for the sake of some information about a dead girl whose face she had never even set eyes upon? 182. The hell what are you even supposed to know? 183. She swore at the woman in her head.

184. The woman somehow read Kabria's thoughts 185. and quickly resumed as though on cue, 186. and said, 187. "Actually, I didn't come to meet the body." 188. She paused, 189. waiting for Kabria to pose her next question.

190. Kabria didn't. 191. She sat there boiling inside; 192. struggling to suppress the growing urge to whack the woman across her discolored cheeks. 193. DID she think 
194. shesold Adade for such cheap and porous information? 195. The woman spoke again. 196. "If you like, 197. I'll grant you some few minutes with my senior apprentice. 198. She is the one out there in the pink blouse. 199. She knows more."

200. Kabria sighed with relief. 201. "thank you", 202. she muttered 203. and walked out onto the extended plank in front of the kiosk 204. Where some of the apprentices were seated on benches and in chairs, 205.gossiping about boyfriends and co-tenants 206. and plaiting the hairs of some customers 207. who were seated on low wooden stools in front of them. 208. The painstaking process of joining, bit by bit, the thin strands of long fake hair by inter-braiding them with the original on the head, always made a fascinating sight.

209. The senior apprentice, a large-boned copper-colored woman of about twenty-four, co-operated with Kabria on the orders of her madam, 210. which were shouted across at her.

211. "when I arrived, 212. there was a small crowd gathered around the body", 213. she began, 214. "people were arguing about215. Whether she died here or somewhere else216. and was dumped here. 217. And before the police came 218. and carted her away, 219. something interesting happened with the reporter from the FM station. 220.I am not sure of which one, but..."

221. " something interesting happened?"

222. "YES. 223. At first, everybody assumed 224. and thought 225. That the girl was a Kayayoo, 226. So this reporter began to interview some of them."

227. "The kayayoos?"

228. "YES. 229. But after he spoke with two of them, 230. their leader came 231. and told them something. 232. No one knew what. 233. But after it all of them became tight lipped. 234. They refused to talk even to the police too."

235. "What about the two who spoke with the reporter before their leader's intervention?"

236. " They disappeared. Just like that," 237. she said, indicating the swiftness with the snap of her fingers. 238. "Suddenly they couldn't be located anywhere around here. 239. The police looked for them in vain. 240. Then they gave up."

241. "DO you know 242.what they told the reporter 243. Before they disappeared?"

244. "Oh YES! 245. Many people heard them. 246. They said247. the dead girl was definitely not one of them. 248. They know one another very well249. you know."

250. "So what conclusion did people draw?"

251. "the conclusion? 252. ISN'T that obvious? 253.Someone didn't want the kayayoos to keep telling people 254. That the dead girl was not one of them. 255. Simple. Or?256. Which means that 257.somebody wants people to believe 258. That she was a kayayoo. 259 . DON'T you agree? 


\section{Macrothink}

International Journal of Linguistics

ISSN 1948-5425

2021, Vol. 13, No. 6

260. " $\underline{\text { But who }}$ can wield that kind of power around here as to issue such an order to the kayayoos through their leader 261. and have it obeyed?"

262. The senior apprentice shrugged 263. and said, 264. "Who knows? With Sodom and Gomorrah just across the streets? 265. Moreover, what did the kayayoos really have to lose 266.If the dead girl wasn't one of them? 267. Nothing. 268. Theirs is to work269. and make money. 270. And if a girl found dead here is not one of them, 271.ISN'T itall the better for them?"

272. One of the girls called the senior apprentice 273. And said, "SENIOR, what about the white fowl?"

274. "Oh yes," 275.the senior apprentice responded, 276. "WAS it three days after, 277.I think so. 278. YES. 279. When I reported for work, 280. a pure white fowl was lying slaughtered at the spot 281. where the body was found."

282. "What happened then?"

283. "Oh. One of the market pastors came 284. and prayed over it, 285. After which a man took it away. 286. Probably ended up in his wife's soup bowl that evening. 287. It was a really fat fowl."

288. Kabria noticed one of the apprentices staring at her curiously. 289. $\underline{\text { She }}$ smiled290. and turned her head shyly away 291. When Kabria gazed back at her.

292. IS there something else 293. you can tell me?" 294. Kabria asked the senior apprentice, 295.who pondered briefly 296. and answered in the negative. 297. Kabria thanked her298. and went back inside the kiosk 299. and thanked the madam too. 300. She cast a final look at the girls 301. As she left the salon 302.and caught them all staring at her303. and whispering among themselves. 304. Then the senior apprentice said aloud to her, 305."SISTER, it's like 306. we have seen you somewhere before. 307. Your face looks familiar."

308. "Me? well, MAYBE somewhere in this market. 309. I come here a lot." 310. She hurried out.

311. " $\underline{A h}$ ! I am sure of it!" 312. the junior apprentice exclaimed 313. After kabria was gone. 314. "It was she. 315. She was the woman 316.whose purse was picked by that boy yesterday." 


\section{Macrothink}

International Journal of Linguistics

ISSN 1948-5425

2021, Vol. 13, No. 6

\section{Excerpt N0 2}

1. Having been briefed by Odarley on the way, 2. she greeted no one else aside from NaaYomo 3. When she entered the house; 4.then joined Odarley in front of the fifth room.

5. "MOTHER", she acknowledged MaaTsuru without emotion.

6. "FOFO,"MaaTsuru responded with difficulty 7. $\underline{\text { and }}$ asked immediately, 8. "DID he do something to you?"

9. Before Fofo replied, 10. MaaTsuru glanced across at NaaYomo. 11. The old lady had fixed a stare on them. 12. MaaTsuru grew nervous.

13. "SHALL we go inside the room?" 14. She entered first. 15. Fofo followed. 16. Odarley remained outside.

17. The room was partitioned with an old translucent curtain. 18. Fofo's four-year-old other half brother was asleep on a mat on the floor in the space in front of the curtain 19. which served as the living room. 20. MaaTsuru raised 21. and pegged one corner of the curtain onto the line 22. and entered the inner space, 23. which was the bedroom. 24. She slumped onto the bed 25. and waited. 26. Fofo hesitated, 27. then moved 28. and sat down carefully at the farthest point from her mother.29. Life on the streets made mixed up persons out of children. 30. She looked about the room 31. and backed at MaaTsuru. 32. Something did not quite fit. 33. Then it dawned on her 34. something was wrong. 35. Something was missing.

36. "where is he, mother?" 37. she asked MaaTsuru

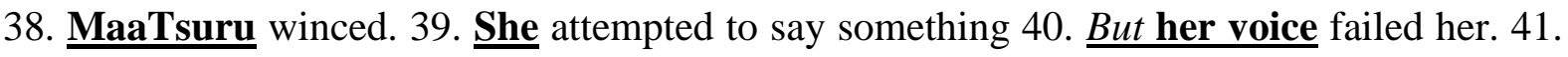
She paused, 42. swallowed saliva 43. and tried again.

44. "He left," 45. she said simply

46. "He left?" 47. it was a wail of pain. 48. "After all that he did to Baby T? 49. To us all? 50. He left? 51. And you stood by 52. And just allow this smallish man to leave? Just like that?"

53. Tears welled up in MaaTsuru's eyes. 54. She did not speak. 55. She couldn't.

56. "What made him leave, mother? 57. Fofo howled on, 58. "and before he left, 59. DID you remind him of 60. What you did for his sake? 61. What you sacrificed? 62. DID you?"

63. MaaTsuru began to weep.

64. "I asked you, mother. 65. DID you?

66. MaaTsuru began to cry. 67. “Go away, Fofo,"68.she managed between tears. 69. “Go!"”

70. Fofo's face clouded fiercely. 71. "IS history repeating itself here? 72. ARE you sacking me, mother? Because of him?" 


\section{Macrothink}

International Journal of Linguistics

ISSN 1948-5425

2021, Vol. 13, No. 6

73. "No! No! I am not sacking you from here. Not from this room. Not from this house. 74. I mean to say, 75. go away. 76. (o away) From Accra, if possible, Fofo. 77. Go away. 78. Go somewhere far away from here 79. Where he can never find you."

80. "What are you talking about, mother? 81. IS it Poison? 82. What does he want with me?"

83. "oh, CHILD, go away!" 84. MaaTsuru sobbed, 85. "ㅁo."

86. "Why mother? Why?"

87. "Because they are animals. 88. They know no mercy. 89. And my hands are tied. 90. PLEASE, Go!"”

91. A part of Fofo was 92. and would always remain the fourteen year-old93.that she was; 94. But the harshness of life on the streets had also made a premature adult of part of her. 95. She was both a child and an adult 96. and she could act like both, 97.talk like both, 98 . think like both99. and feel like both.100. What she wanted to do was to say a whole lot of things to hurt MaaTsuru, 101. and cause her pain. 102. But she held back. 103. Her mother was still not making complete sense.

104. "Why should I go away, mother? 105. Who are they?"

106. MaaTsuru wiped away her tears with the back of her hand 107. and blew her nose into her cover cloth.108."It's Baby T," 109. she said eventually.

110. "Baby T?"

111. "YES. MaamiBroni..."

112. "The fat fair woman she lives with?"

113. "YES. 114. She came to me last week."

115. "S $\underline{S o}$ ? Doesn't she sometimes come to..."

116. “I know Fofo. 117. I know. Oh God!”

118. "Don't bring in God's name, mother. 119. You knew 120. What you were doing 121. When you chose him over..."

122. "It was for their sake," 123. she pointed at the baby and the sleeping boy. 124. "What should I have done?"

125. "I don't know. 126. But you should never have fed him and his sons at Baby T's expense. 127. You don't see her. 128. I don't see her. 129. We don't know130. how she has grown to look like. All for what, mother? For what?

131. MaaTsuru didn't respond. 132. She wiped away fresh tears from her face 133. And resumed 134.from where she had left off. 135. "Something happened, Fofo." 
136. "Something is always happening, no? Always. 137. And HAD I not got the good sense to leave home, 138. he probably would have made you send me away too to work for some women to make money for you four to leave on. No?"

139. MaaTsuru chocked on saliva 140. and coughed violently.141. "I don't have the strength to fight you with words Fofo," 142. she said slowly, 143. "And even if I did, 144. I wouldn't do it."

145. Fofo said nothing.

146. MaaTsuru went on; 147. "Last week a body was found behind a blue rasta hairdressing kiosk salon at Agbogbloshie. 148. DID you hear about it?"

149. "AREN'T bodies always being found there like the aborted fetuses at Sodom and Gomorrah? 150. IS that news? 151. Well, MAYBE, for people like you living in proper homes like here, 152.it is, no?"

153. MaaTsuru ignored the sarcasm to avoid the bait of another round of war with words, 154. for what she was about to say was in itself, war enough. 155. "Maami Broni didn't come to give me money, Fofo. 156. She came 157. Because she was afraid."

158. Fofo frowned. 159. Her unasked question was obvious.

160. MaaTsuru went on. 161. "Since she was the one 162. I entrusted Baby T to, 163. she..."

164. "What are you trying to say, mother?"

165. "She came to tell me."

166. "Tell you what?"

167. "That the body behind the hairdressing salon..." 168 fresh tears chocked the rest of her words.

169. Fofo's eyes widened. 170. "Baby T?"

171. MaaTsuru began to shake.

172. Fofo just sat there 173. and stared at her. 174. She felt no immediate pain. 175. Even the anger and mixed feelings lay low. 176. In her mind's eye was a recollection of the last time 177. she laid eyes on her sister: Baby T's reddish and swollen eyes from too much crying, with her belongings tied up in an old headscarf and held loosely in her right hand 178. As she followed Maami Broni out of the compound house.

179. Her calmness, when she opened her lips again to address MaaTsuru, surprised her own self. 180. "MOTHER, what is happening? 181. Where do I fit into all this? 182. What has all this got to do with Poison?"

183. "He got upset 184. When he heard of Maami Broni's visit to me. 185. He knew she had come to tell me." 
186. "Tell you what? 187. ARE you saying 188. Baby T is dead?"

189. MaaTsuru nodded

190. Fofo didn't know 191. what to think. 192. "So Baby T is dead?"

193. MaaTsuru nodded again

194. Fofo was scared and confused and in great emotional pain all at once. 195. "My sister was staying with Maami Broni. 196. Then she dies. 197. So Maami Broni comes to inform you about it. 198. You, who are her mother. 199. And because of that, Poison gets upset? 200. For which reason he tries to rape me? 201. It doesn't make sense to me. 202. What does it all mean?"

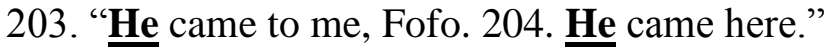

205. "What?"

206. "He came here 207. and turned me into a leper."

208. "So that was 209. why the woman in the third room didn't respond to Odarley's greeting?"

210. "211. And why you should also go away from here; 212. he told me 213. you."

214. "Me?"

215. "YES. 216. And he swore to replace Baby T with you 217. If we made him angry."

218. "ㄹeplace? 219. Make him angry? 220. What are you saying mother? 221. What is all this roundabout talk?"

222. "Look, Fofo, 223. PLEASE, go away."

224. The sleeping anger in Fofo awakened. 225. "It's all you keep telling me. 226. Go away; 227. go away!" 228. Fofo yelled! 229. "How do I just go away? Somewhere, mother? 230. Whereshould I go? 231. I have nothing on me. 232. I got a job at the vegetable market just a few days ago. 233. I tried to stop stealing. 234. But the little I had on me too, 235. I just lost to Matcho. 236. So 2tell me something better."

237. "I have nothing better to tell you, child, 238. and no money to give you, too." 239. MaaTsuru cried. 240. "I looked on 241. and allowed something to happen 242. that shouldn't have happened. 243. My hands are tied. 244. I have my fingers between his teeth. 245. If I hit him on the head, 246. I will make him chew off my own finger too inside his mouth. 247. Then what would happen to them?" 248. she asked 249. and paused, pointing again at her sons, 250. "Look at them;" 251. she went on, no longer crying but clearly hurting. 252."What have they done? 253. Their only crime is 254 . That they came into the world through me." 


\section{MInstitute Macrothink $_{\text {Int }}^{\text {Instion }}$}

255. age gripped Fofo. 256. "Is their father still your husband? 257. You said 258. he left, no?"

259. MaaTsuru broke down. 260. She began to cry again. 261. "Don't talk to me like that, Fofo," 262. she sniffed. 263. "JUST because I made a lot of mistakes in life 264. and I am poor, 265. it doesn't make me less your mother. 266. So don't talk to me that way."

267. Fofo's heart churned. 268. She looked at her mother long 269. and then turned her face away." 270. "I don't like coming to see you, mother," 271. she began slowly, 272. “Odarley's mother sacks her like a fowl273. When she goes to see her. 274. She says Odarley is a thief. 275. You don't sack me 276. When I come to see you. 277.Yet I don't like coming to see you 278. Because I don't like 279. what I feel280. when I come to see you, mother. 281. I don't."

282. MaaTsuru looked away 283. and stared into the outside void through the tiny window. 284. Fofo's outpouring didn't shock her. 285 . It wasn't the first time 286 . Fofo had said this to her. 287. But somewhere inside her, she said a silent prayer, 288. that SOMEHOW something would happen to make it the last.

289. "MOTHER." Fofo resumed. 290. Her voice was calm and steady; too calm and too steady, 291. "Why was Poison upset about Maami Broni coming to tell you about Baby T?"

292. "He didn't want me to know 293. That Baby $\mathbf{T}$ was dead."

294. "Just that?"

295. MaaTsuru pursed her lips 296. and refused to respond.

297. “But Maami Broni came to tell you anyway."

298. "YES. 299. She was afraid. 300. If Baby T was made out, 301. someone was bound to remember 302. thatshe was staying with her"

303. Fofo felt exhausted. 304. "DID anyone say what happened? 305. Why Baby T died?"

306. "Poison only said 307. it was Baby T's own fault."

308. Fofo digested that 309. and chuckled bitterly. 310. "So how do you feel, mother?"

311. "How I feel? 312. How I am supposed to feel? 313. How do you suppose 314.I should feel? 315. DO you know 316. what Poison told me to the face? 317. That Baby T ceased to be my daughter 318. the day I sold her to the streets. 319. I sold her to the streets? 320. I sold my own daughter to the streets? 321. Oh God!" she broke down again.

322. Fofo remained calm and unimpressed.

323. "I carried her for nine months in my womb." 324. MaaTsuru cried on. 325."I screamed in pain 326. When I was bringing her forth. 327. And look where she ended up dying? Under the open skies behind a kiosk at the market place? 328. And all $\underline{\mathbf{I}}$ have left is my anger at the world. 329. Oh God!" she noticed Fofo studying the blue and white plastic rattan bag in the 
corner near the bed. 330. "DO you need it?" 331. she asked Fofo calmly, 332. THINKING Fofo needed it to pack in her few belongings and get away from Accra.

333. Fofo turned her attention from the bag, 334. And it was like 335. she had aged ten years more within the last few seconds.

336. “I can give it to you 337. if you need it," 338. MaaTsuru offered.

339. “I don't need the bag,"340.Fofo retorted. 341. "ㅁoes he have some things inside?"

342. "A few of his clothes.343. YES. 344. He left without warning. 345. He just left."

346. "I don't really care about that, mother," 347. Fofo snapped 348. and rose to the bag, thankful for her stepfather's smallish frame. 349. She unzipped it. 350. Inside was sparse, the leftovers of a man neither here nor there. 351. Not there for the wife, not there for the sons, yet, not gone completely from their lives either. 352. She rummaged through 353. and picked out an old pair of shorts; a faded checkered skirt torn at one shoulder; and a crumpled old baseball cap which still carried a pungent smell. 354. Her four-year-old half-brother was up 355. by the time she was through with her pick 356. and was all over MaaTsuru on the bed like his baby brother.357. Fofo paid them no attention.

358. "I'm off!" 359. she announced brusquely, 360. and stepped out of the room.

\section{Copyrights}

Copyright for this article is retained by the author(s), with first publication rights granted to the journal.

This is an open-access article distributed under the terms and conditions of the Creative Commons Attribution license (http://creativecommons.org/licenses/by/4.0/) 